\title{
Mathematical Simulation of Thermal Stress State of Microturbine Casing Shell Elements
}

\author{
Vladislav Sergeevich Popov, Aleksey Fedorovich Kolbasov, Kirill Evgenievich Karpukhin \\ Federal State Unitary Enterprise Central Scientific Research Automobile and Automotive Institute "NAMI"
}

(FSUE «NAMI»), Moscow, Russia

\begin{abstract}
This article discusses thermal state of microturbine casing aiming at determination of structural deformations and stresses. Application of rotary heat exchanger in microturbine design makes it necessary not only to use floating labyrinth seals but also to consider for thermal deformations in working mode. Peripheral seals take into account structural deformations but cannot operate upon significant movements of casing. Possible leaks and mixing of blown air and waste gases can decrease significantly the unit efficiency. In order to solve the problem, 3D model has been developed comprised of major elements of microturbine casing: rotor support and compressor housing, turbine housing, heat exchanger flanges, turbine casing with combustion chamber, exhaust diffusor and inlet gas flange, heat exchanger casing, heat exchanger framing. Mathematical simulation of thermal stress state of casing elements is based on finite element method in ANSYS Workbench. Thermal boundary conditions of the third kind were used. Coefficients of heat dissipation and reference air temperatures in respective cavities were preset on surfaces of casing elements. Such solution made it possible to determine deformations of overall structure and of single elements with the most important in this case being the support of peripheral seals of heat exchanger.
\end{abstract}

Key words: microturbine, high efficiency, regenerative heat exchanger, thermal stress state, thermal expansion, thermal problem, gas turbine engine.

\section{INTRODUCTION}

Extensive use of energy-efficient automobiles requires for new method of energy generation with minimum $\mathrm{CO} 2$ emissions, since electric car in pure form is characterized by numerous disadvantages. Due to imperfections of battery cells, on-board independent energy sources are used with increasing frequency. One of the most successful energy sources is a high efficiency microturbine $[1,2]$. Such engines are characterized by certain advantages: moderate weight, simple maintenance and no vibrations [3, 4]. Development of microturbines for vehicles as electric generation unit can be promising both for heavy-duty vehicles and for agricultural machinery.
One of the main reserves to improve efficiency of modern microturbines is the increase in regeneration rate of their heat exchangers $[5,6,7]$. Increase in regeneration rate of heat exchanger results in significant increase in its dimensions. It is known that rotary heat exchangers are characterized by the best compactness. Designs of rotary heat exchanger with the regeneration rate of $95-97 \%$ are known $[8,9]$, whereas the regeneration rate of stationary heat exchangers in general equals to $90 \%$. In particular, the regeneration rate of the heat exchanger of one of the best microturbines (Capstone) is $86 \%$ [10].

Development of microturbines for vehicles as electric generation unit can be promising both for heavy-duty vehicles and for agricultural machinery.

In the course of designing of $50 \mathrm{~kW}$ microturbine, mathematical tests were performed to analyze thermal stress state of casing elements, which finally allowed to determine thermal state of casing elements and occurring movements and stresses.

\section{RESEARCH OBJECTIVES}

Thermal deformation of microturbine casing was analyzed and, respectively, selection of materials for the obtained temperatures was conducted by means of mathematical analysis. The research objective is presented by casing of designed $50 \mathrm{~kW}$ microturbine.

\section{RESEARCH METHODS}

Mathematical simulation of thermal stress state of casing elements was performed using finite element method in ANSYS Workbench 19, Steady-State Thermal and Static Structural software modules.

Finite element flowcharts for computation of stress strain state of microturbine casing elements are illustrated in Figures. 1-2. They include the most important units of the system, namely: heat exchanger casing, heat exchanger framing, exhaust diffusor, and inlet flanges.

Casing was simulated using 3D tetrahedral four-node finite elements. Sheet fragments of the systems were simulated using four-node shell elements. 


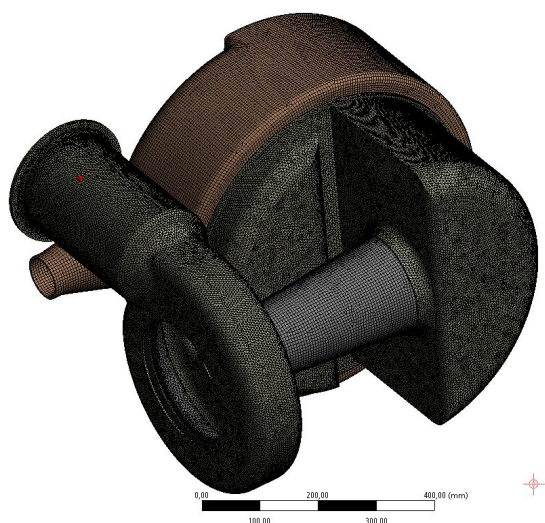

Figure 1: Finite element model of microturbine casing

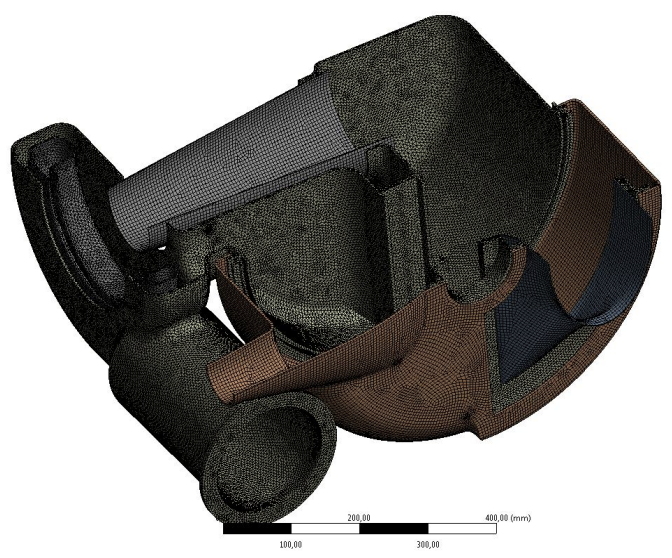

Figure 2: Cross section of finite element model of microturbine casing

\section{MICROTURBINE DESIGN}

While developing power generating unit, mathematical finite element models of the most important microturbine units were developed. On their basis, strength and gas dynamic properties of the system were calculated. As a consequence, the optimum design solutions for the system were obtained (Figs. 3, 4).

This structure is comprised of the following elements:

1) rotor support and compressor housing;

2) turbine housing;

3) heat exchanger flanges;

4) turbine casing with combustion chamber;

5) exhaust diffusor and inlet gas flange;

6) heat exchanger casing;

7) heat exchanger framing.

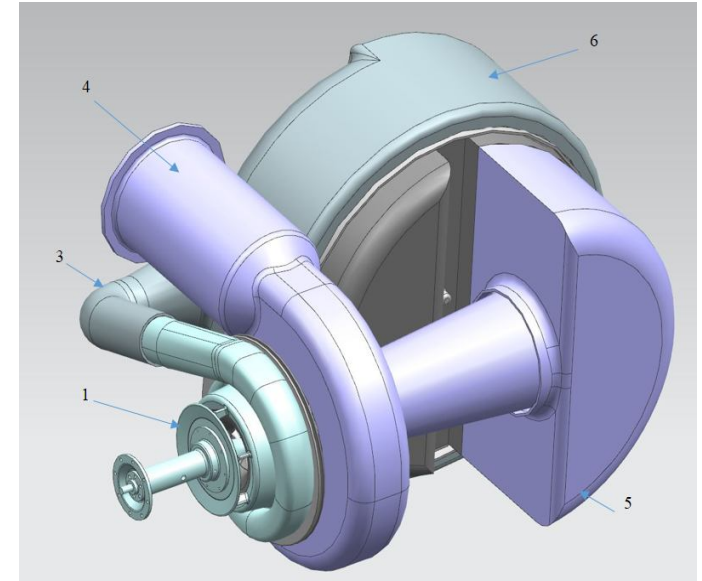

Figure 3: General view of the considered structure

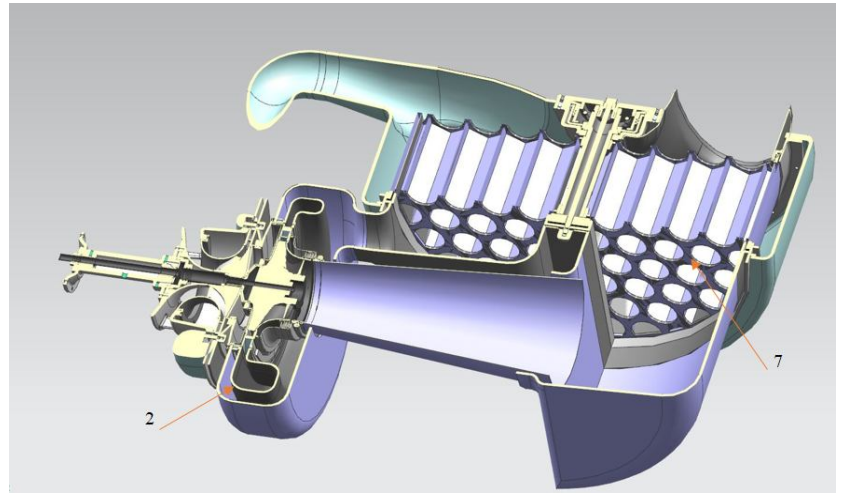

Figure 4: Cross section of the considered structure.

The microturbine is made of heat-resistant alloys, aluminum, alloyed steel, and cast iron. Selection of these materials is a consequence of higher temperatures of hot heat carrier in the combustion chamber, which heats turbine housing, turbine impeller machine, diffusor and inlet gas flange to high temperatures. The rotor support is an integral part of compressor housing, it is made of cast iron. In order to operate the microturbine in combination with the heat exchanger, it is required to supply air from compressor via regenerator to the combustion chamber, which requires for additional high-pressure pipelines with operation temperature of about $300^{\circ} \mathrm{C}$, made of aluminum. The flanges supplying gas to heat exchanger and removing air are made of alloyed steel [11].

\section{STRUCTURAL MATERIALS}

Application of materials with different thermal and mechanical properties requires for accounting of their thermal stress state [12]. Thermal deformations of microturbine elements require for use of movable junctions between adjacent units to reduce mechanical stresses [13]. Thus, due to the temperature difference between the turbine casing with hot heat carrier (waste gases) and the heat exchanger casing with cold heat carrier (air passing from the compressor via the heat exchanger to the combustion 
chamber), it is required to account for linear movements and stresses in connecting gas air flange.

Various materials were used for the facility. The rotor support and the compressor housing are made of cast iron, grade SCh20; the turbine housing, the turbine casing with the combustion chamber, the exhaust diffusor and the inlet gas flange are made of heat-resistant VZhL12 alloy; the heat exchanger flanges and its casing are made of aluminum, grade AL32; the heat exchanger framing is made of steel, grade $40 X$.

The temperature-dependent properties of the applied materials are summarized in Tables 1-4.

Table 1: Properties of steel, grade 40X

\begin{tabular}{|l|l|l|l|}
\hline $\mathrm{T},{ }^{\circ} \mathrm{C}$ & $\mathrm{E}, \mathrm{GPa}$ & $\alpha_{\mathrm{T}}, 10^{-6} /{ }^{\circ} \mathrm{C}$ & $\mu$ \\
\hline 20 & 210 & - & \\
\cline { 1 - 3 } 100 & 203 & 11.8 & \multirow{2}{*}{0.29} \\
\cline { 1 - 2 } 200 & 199 & 12.3 & \\
\cline { 1 - 3 } 300 & 190 & 13.4 & \\
\hline 400 & 182 & 14.0 & \\
\hline 500 & 172 & 15.0 & \\
\hline
\end{tabular}

Table 2: Properties of VZhL12 alloy [14, 15]

\begin{tabular}{|l|l|l|l|}
\hline $\mathrm{T},{ }^{\circ} \mathrm{C}$ & $\mathrm{E}, \mathrm{GPa}$ & $\alpha_{\mathrm{T}}, 10^{-6} /{ }^{\circ} \mathrm{C}$ & $\mu$ \\
\hline 20 & 190 & 12.0 & \\
\cline { 1 - 3 } 800 & 146 & 17.8 & \multirow{2}{*}{0.29} \\
\cline { 1 - 2 } 850 & - & 19.0 & \\
\cline { 1 - 2 } 900 & 139 & 20.1 & \\
\cline { 1 - 3 } 1,000 & 133 & 25.1 & \\
\cline { 1 - 3 } 1,050 & 116 & 27.5 & \\
\hline
\end{tabular}

Table 3: Properties of AL32 alloy

\begin{tabular}{|l|l|l|l|}
\hline $\mathrm{T},{ }^{\circ} \mathrm{C}$ & $\mathrm{E}, \mathrm{GPa}$ & $\alpha_{\mathrm{T}}, 10^{-6} /{ }^{\circ} \mathrm{C}$ & $\mu$ \\
\hline 20 & 71 & - & \multirow{2}{*}{0.34} \\
\hline 100 & - & 20.4 & \\
\hline
\end{tabular}

Table 4: Properties of cast iron, grade SCh20.

\begin{tabular}{|l|l|l|l|}
\hline $\mathrm{T},{ }^{\circ} \mathrm{C}$ & $\mathrm{E}, \mathrm{GPa}$ & $\alpha_{\mathrm{T}}, 10^{-6} /{ }^{\circ} \mathrm{C}$ & $\mu$ \\
\hline 20 & 100 & 9.5 & 0.3 \\
\hline
\end{tabular}

While solving the heat problem, the heat conductance and the heat capacity were used as a function of temperature for respective materials. Heat conductance as a function of temperature is required for correct calculation of temperature field of parts in the case of significant temperature gradient. The properties of materials for the analysis were determined in the reference books [16].

\section{BOUNDARY CONDITIONS}

In the thermal analysis of casing elements, the heat conductance was used as a function of temperature. The heat conductance as a function of temperature is required for correct computation of temperature field of parts in the case of significant temperature gradient.

Boundary conditions for heat problem correspond to the established mode of engine operation. The temperature gradients along the casing correspond to the solution to stationary heat problem. The boundary conditions include heat transfer on casing surface preset by the boundary conditions of the third kind, comprised of the heat transfer coefficient and reference temperature of ambient environment preset for internal casing surfaces according to Fig. 5.

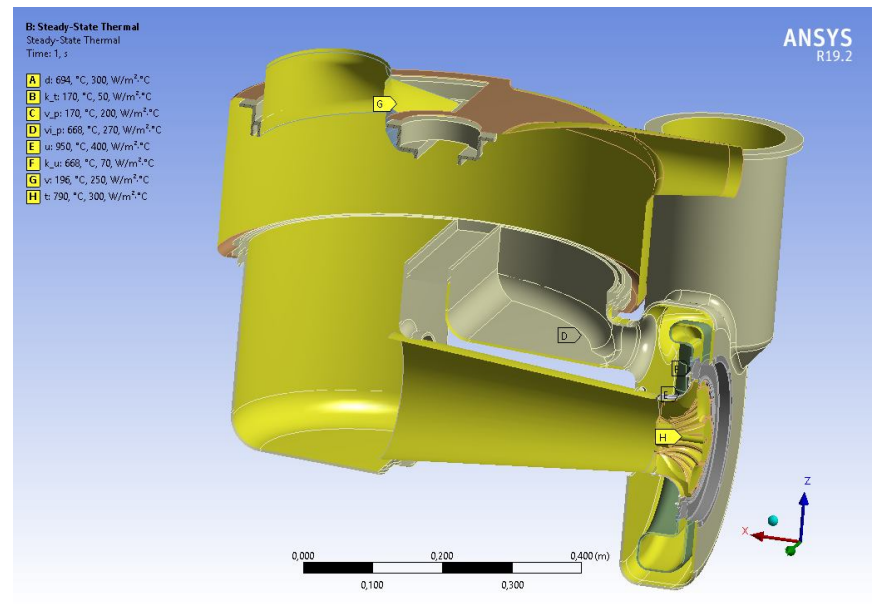

Figure 5: Boundary conditions of the third kind.

It can be seen in Fig. 6 that the highest temperatures are distributed over the walls of exhaust diffusor and inlet gas flange, they can be as high as $668^{\circ} \mathrm{C}$. In the heat exchanger, the temperatures are significantly lower. In the heat exchanger flanges, the temperatures can be as high as $170^{\circ} \mathrm{C}$, which corresponds to the temperature of passing gases.

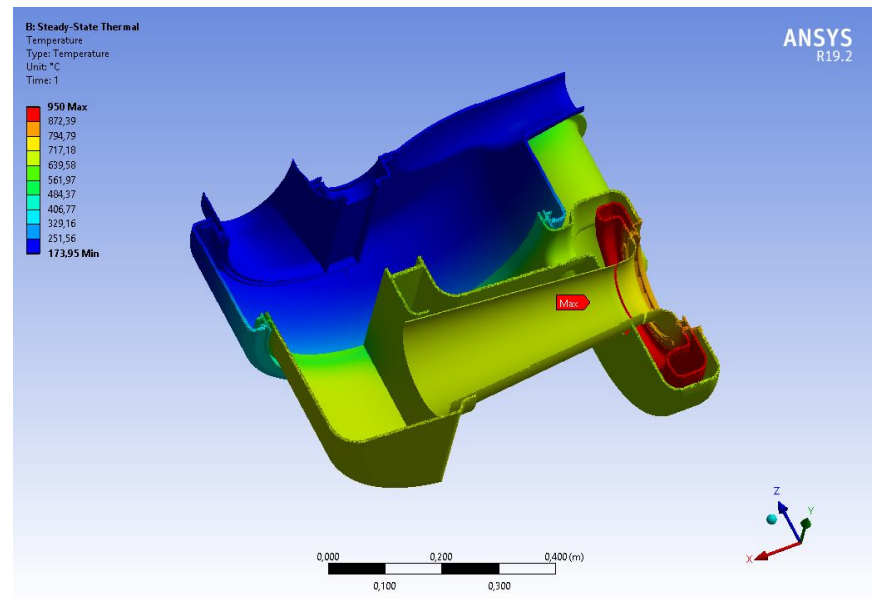

Figure 6: Temperature distribution in microturbine casing. 
After solving the heat problem, it was required to estimate deformations of microturbine casing with consideration for its thermal expansion. With this aim, temperature fields obtained by thermal analysis were applied to the model and the movements in microturbine casing elements (Fig. 7) were analyzed.

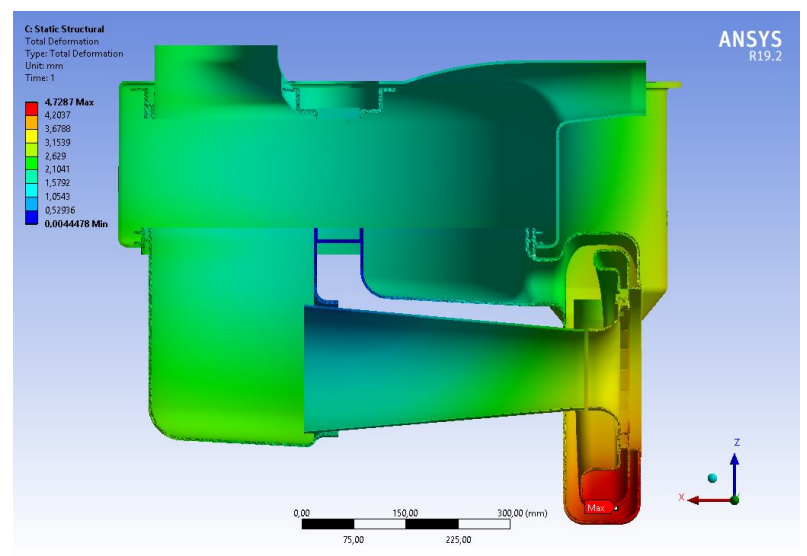

Figure 7: Movements in microturbine casing

This analysis makes it possible to estimate casing deformations in total, as well as in the places of the most important seals of heat exchanger of gas turbine engine, and to perform design modifications if necessary.

The results of numerical analysis demonstrate that the maximum movements in the region of heat exchanger seals do not exceed $2 \mathrm{~mm}$ (Fig. 8).

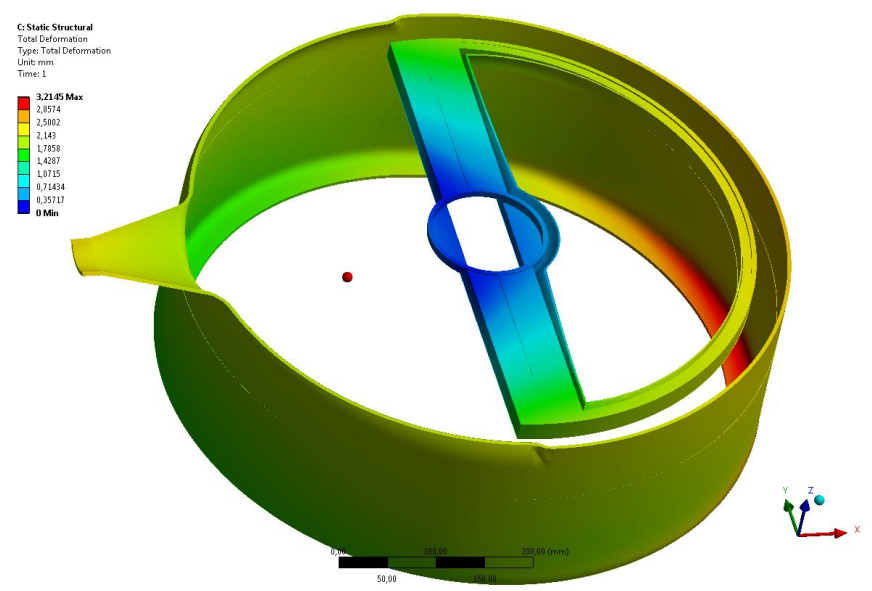

Figure 8: Movements in the region of peripheral seals of heat exchanger

Waste gases cause heterogeneous heating of heat exchanger casing, resulting in its misalignment. Figures 8 and 9 illustrate movements in the region of peripheral seals of heat exchanger casing. It can be seen that the movements are heterogeneous along the seal perimeter, they are misaligned by up to $2 \mathrm{~mm}$.

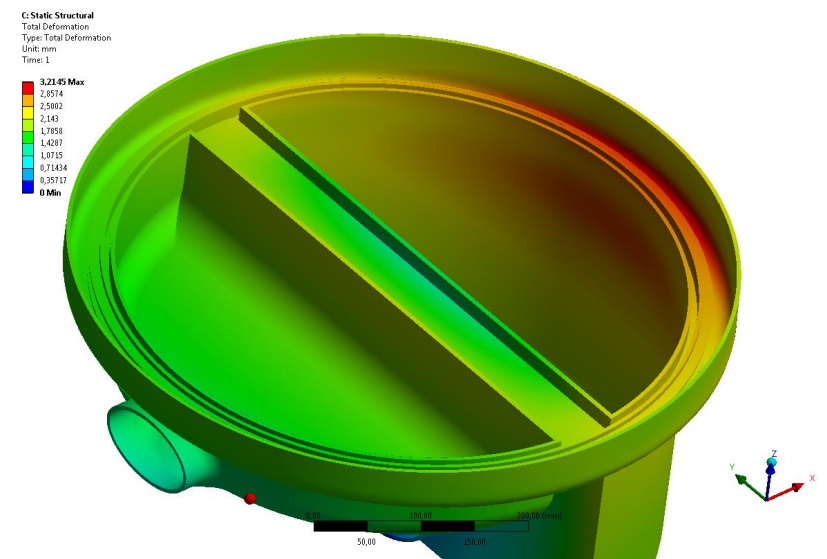

Figure 9: Movements in the area of peripheral seals of heat exchanger

Such distribution of movements is attributed to existence of hot heat carrier (waste gases) in one part and cold heat carrier (air after compressor) in the other part. In order to compensate peripheral movements of casing elements and to decrease heat transfer, pin connections and membrane seals are used in heat exchanger casing.

\section{RESULTS}

Thermal stress state of microturbine casing elements was numerically analyzed using finite element method in 3D formulation. Thermal boundary conditions of the third kind were applied. Coefficients of heat dissipation and reference air temperatures in respective cavities were preset on surfaces of casing elements.

\section{CONCLUSION}

Thermal state of casing elements and occurring movements and stresses were determined.

A variant of heat exchanger casing was developed using peripheral pins and membranes allowing to decrease heat transfer and deformations without losing air tightness.

Maximum temperatures of main heat loaded parts of microturbine casing do not exceed ultimate temperatures, after which mechanical properties of their structural materials are sharply deteriorated.

\section{ACKNOWLEDGEMENT}

This article was supported by the Ministry of Education and Science of the Russian Federation, agreement No. 075-11-2018-233; unique identifier of the project: RFMEFI62518X0045.

\section{REFERENCES}

1. G.L. Touchton, M. Senkevych, A. Belokon, V. Belyaev, A. Novek. Gas Turbine Product Line for on Site Generation and Combined Heat and Power between 400 kWe AND 1.6Mwe, GT2004-54257, 2004. 
https://doi.org/10.1115/GT2004-54257

2. Report Volvo - Microturbine Section 1 Volvo. 2005.

3. P. Akbari, R. Nalim, N. Mueller. Performance Enhancement Microturbine Engines Topped With Wave Rotors. Journal of Engineering for Gas Turbines and Power vol. 128 no. 1, 2006.

4. K.E. Karpukhin A.S. Terenchenko, A.F. Kolbasov, V.N. Kondrashov. The Use of Microturbines as an Energy Converter for Motor Transport. International Journal of Innovative Technology and Exploring Engineering vol. 8 no. 10, 2019.

https://doi.org/10.35940/ijitee.J9451.0881019

5. M. Kelly, M.-J. Pan, S. Atre, G. Rancourt, A. Heyes, M. Vick. Ceramic Micro Channel Recuperator Fabrication Methods for Small Gas Turbine Engines, GT2012-68510, 2012.

6. J.L. Cordova, J.F. Walton, H. Heshmat. High Effectiveness, Low Pressure Drop Recuperator for High-Speed and Power Oil-Free Turbogenerator GT2015-43718, 2015.

7. G. Nadareishvili, A. Kostyukov, K. Karpukhin. Design Features when Using an Effective Microturbine as a Range Extending Engine. Science \& Technique vol. 18 no. 6, pp. 447-460, 2019.

8. D.G. Wilson. The high efficiency of our multistage ceramic-bladed turbine design can produce an attractive economic return even in the absence of CHP. Wilson Solarpower Corporation, 2010.

9. D.G. Wilson, A.C. Pfahnl. A look at the automotive-turbine regenerator system and proposals to improve performance and reduce cost. SAE paper 9270237, Warrendale, PA, 1997. https://doi.org/10.4271/970237

10. B.F. Kolanovski. BSME. Guide to Microturbines. Printed in the USA, 2004.

11. Yu.A. Chumakov. Teplovoi raschet avtotraktornykh gazoturbinnykh dvigatelei [Thermal design of automotive gas turbine engines]: Guidebook. Moscow: MAMI, 1999.

12. F.E. Kal'nitskii. Analysis of thermal state of casings and bearings of regenerative gas turbine engines. Cand. thesis. Moscow, 1981.

13. L.J. Salerno, P. Kittel. Thermal contact resistance. California: NASA Ames Research Center, 1997.

14. V.P. Kuznetsov, V.P. Lesnikov, N.A. Popov. Materialovedenie: Monokristallicheskie zharoprochnye nikelevye splavy [Material science: monocrystalline heat-resistant nickel alloys]: Guidebook. Moscow: Yurait, 2020.

15. Vestnik VIAM. Zharoprochnye nikileevye splavy nizkoi plotnosti [Heat-resistant low-density nickel alloys], February, 2012.

16. A.T. Tumanov. Aviatsionnye materialy [Aviation materials]. Reference book in nine volumes. Moscow: ONTI, 1975. 